\title{
A tropical Atlantic species of Melibe Rang, I 829 (Mollusca, Nudibranchia, Tethyiidae)
}

\author{
Erika Espinoza ${ }^{1, \dagger}$, Anne DuPont ${ }^{2, \ddagger}$, Ángel Valdés ${ }^{1, \S}$ \\ I Department of Biological Sciences, California State Polytechnic University, 3801 West Temple Avenue, Pomo- \\ na, California 91768, USA 24070 NW 7th Lane, Delray Beach, Florida 33445, USA \\ † urn:lsid:zoobank.org:author:9B1ADF42-1CDF-4CAA-A2BB-0394695C2E96 \\ ¥ urn:lsid:zoobank.org:author:F3469A4A-29CA-43AD-9663-1ECD09B067A1 \\ § urn:lsid:zoobank.org:author:B5F56B28-F105-4537-8552-A2FE07E945EF \\ Corresponding author: Ángel Valdés (aavaldes@csupomona.edu)
}

Academic editor: Robert Hershler | Received 3 May 2013 | Accepted 1 July 2013 | Published 11 July 2013

urn:lsid:zoobank.org:pub:7F156A4D-1925-464C-A0D4-8E4B40241DA3

Citation: Espinoza E, DuPont A, Valdés Á (2013) A tropical Atlantic species of Melibe Rang, 1829 (Mollusca, Nudibranchia, Tethyiidae). ZooKeys 316: 55-66. doi: 10.3897/zookeys.316.5452

\begin{abstract}
A new species of Melibe is described based on two specimens collected in Florida. This new species is well differentiated morphologically and genetically from other species of Melibe studied to date. The four residue deletions in the cytochrome $\mathrm{c}$ oxidase subunit 1 protein found in all previously sequenced tropical species of Melibe sequenced (and Melibe rosea) are also present in this new species. These deletions do not appear to affect important structural components of this protein but might have fitness implications. This paper provides the first confirmed record of Melibe in the tropical western Atlantic Ocean.
\end{abstract}

\section{Keywords}

new species, molecular taxonomy, anatomy, Opistobranchia, western Atlantic

\section{Introduction}

Melibe Rang, 1829 (family Tethyiidae Rafinesque, 1815) is an unusual genus of cladobranch nudibranchs that feed by expanding a large oral hood fringed with sensory tentacles to capture small crustaceans. The digestive morphology of this group is largely modified, all species lack a radula and have a circularized stomach (Gosliner and Smith 2003).

Copyright Erika Espinoza et al. This is an open access article distributed under the terms of the Creative Commons Attribution License 3.0 (CC-BY), which permits unrestricted use, distribution, and reproduction in any medium, provided the original author and source are credited. 
Gosliner and Smith (2003) reviewed the systematics of Melibe and concluded that there are 14 valid species and three uncertain species. According to Gosliner and Smith (2003) Melibe includes a mixture of temperate and tropical species. Temperate species include $M$. australis (Angas, 1864) and M. maugeana Burn, 1960 from southern Australia, M. leonina (Gould, 1852) from California, and M. rosea Rang, 1929 and M. liltvedi Gosliner, 1987 from South Africa. Most tropical species have widespread ranges in the tropical Indo-Pacific including $M$. viridis (Kelaart, 1858), M. pilosa Pease, 1860, M. papillosa (de Filippi, 1867), M. bucephala Bergh, 1902, M. engeli Risbec, 1937, M. megaceras Gosliner, 1987, and M. digitata Gosliner \& Smith, 2003. Only M. minuta Gosliner \& Smith, 2003 and M. tuberculata Gosliner \& Smith, 2003 appear to have restricted ranges (in Okinawa and the Philippines, respectively). In a recent paper Gosliner and Pola (2012) described two additional new species, M. coralophilia Gosliner \& Pola, 2012 and M. colemani Gosliner \& Pola, 2012, both from the tropical Indo-Pacific and provided the first molecular phylogeny for this group conforming the sister-group relationship of Melibe with Tethys Linnaeus, 1767, and the monophyly of both Melibe and Tethyiidae.

Melibe is also unusual biogeographically as it appears to be completely absent from the tropical Eastern Pacific and is poorly represented in the Atlantic Ocean. The only two confirmed records from the Atlantic are the two South African species $M$. rosea and $M$. liltvedi, which are found on the Atlantic side of the Cape Peninsula. Melibe viridis has been reported from the Mediterranean - originally as M. fimbriata (Alder \& Hancock, 1864), but is considered a non-native species (Thompson and Crampton 1984). The only record of Melibe in the tropical Atlantic Ocean is a photograph of a potentially undescribed species found in Guanaja, Honduras, Caribbean Sea (Valdés et al. 2006), but this record has never been confirmed with the examination of specimens.

In this paper we describe the first species of Melibe from the tropical Atlantic Ocean based on two specimens recently collected in Florida. Molecular and morphological data obtained from the two specimens are compared with other congeners.

\section{Methods}

\section{Source of specimens and morphological examination}

Two specimens were collected by SCUBA diving in Lake Worth Lagoon Florida, photographed alive, and preserved in pharmacy grade ethyl alcohol. Once in the laboratory they were transferred to ethanol 95\%. All the specimens examined are deposited at the Natural History Museum of Los Angeles County, USA (abbreviated LACM).

The anterior portion of the digestive system and the reproductive system were dissected and drawn under a dissecting microscope with a camera lucida attachment. The stomach was also dissected to expose the stomach plates. The buccal mass was dissolved in a $\mathrm{NaOH} 10 \%$ solution to isolate the jaws. The jaws and the stomach were rinsed in distilled water, dried, mounted on a stub, and sputter coated for examination under a scanning electron microscope (SEM) Hitachi S-3000N. 


\section{DNA extraction, PCR amplification and sequencing}

DNA extraction was performed using a hot Chelex ${ }^{\oplus}$ protocol. Approximately 1-3 mg of the foot was cut into fine pieces for extraction. For the Chelex extraction, the foot tissue was rinsed and rehydrated using $1.0 \mathrm{~mL}$ TE buffer $(10 \mathrm{mM}$ Tris, $1 \mathrm{mM}$ EDTA, $\mathrm{pH}$ 8.0) for 20 minutes. A 10\% (w/v) Chelex 100 (100-200 mesh, sodium form, Bio-Rad) solution was prepared using TE buffer. After rehydration, the tissue mixture was then centrifuged, $975.00 \mu \mathrm{L}$ of the supernatant was removed, and $175.00 \mu \mathrm{L}$ of the Chelex ${ }^{\oplus}$ solution was added. Samples were then heated in a $56^{\circ} \mathrm{C}$ water bath for 20 minutes, heated in a $100^{\circ} \mathrm{C}$ heating block for 8 minutes, and the supernatant was used for PCR.

Histone-3 universal primers (H3 AF 5'-ATGGCTCGTACCAAGCAGACGGC-3', H3 AR 5'-ATATCCTTGGGCATGATGGTGAC-3' developed by Colgan et al. 1998), 16S rRNA universal primers (16S ar-L 5'-CGCCTGTTTATCAAAAACAT-3', $16 \mathrm{~S}$ br-H 5'- CCGGTCTGAACTCAGATCACGT-3' developed by Palumbi 1996), and CO1 universal primers (LCO1490 5'-GGTCAACAAATCATAAAGATATTGG-3', HCO2198 5'-TAAACTTCAGGGTGACCAAAAAATCA-3' developed by Folmer et al. 1994) were used to amplify the regions of interest for all specimens.

The master mix was prepared using $34.75 \mu \mathrm{L} \mathrm{H} 2 \mathrm{O}, 5.00 \mu \mathrm{L}$ Buffer B (ExACTGene, Fisher Scientific), $5.00 \mu \mathrm{L} 25 \mathrm{mM} \mathrm{MgCl} 2,1.00 \mu \mathrm{L} 40 \mathrm{mM}$ dNTPs, $1.00 \mu \mathrm{L}$ $10 \mathrm{mM}$ primer $1,1.00 \mu \mathrm{L}$ primer $2,0.25 \mu \mathrm{L} 5 \mathrm{mg} / \mathrm{mL}$ Taq, and $2.00 \mu \mathrm{L}$ of extracted DNA. Reaction conditions for $\mathrm{H} 3$ (universal) and $16 \mathrm{~S}$ (universal) were as follows: lid heated to $105^{\circ} \mathrm{C}$ and initial denaturation of $94^{\circ} \mathrm{C}$ for $2 \mathrm{~min}, 35$ cycles of $94^{\circ} \mathrm{C}$ for $30 \mathrm{~s}, 50^{\circ} \mathrm{C}$ for $30 \mathrm{~s}$, and $72^{\circ} \mathrm{C}$ for $1 \mathrm{~min}$, followed by a final elongation of $72^{\circ} \mathrm{C}$ for 7 min. Reaction conditions for $\mathrm{CO} 1$ (universal) were as follows: lid heated to $105^{\circ} \mathrm{C}$ and initial denaturation of $95^{\circ} \mathrm{C}$ for $3 \mathrm{~min}, 35$ cycles of $94^{\circ} \mathrm{C}$ for $45 \mathrm{~s}, 45^{\circ} \mathrm{C}$ for $45 \mathrm{~s}$, and $72^{\circ} \mathrm{C}$ for $2 \mathrm{~min}$, followed by a final elongation step of $72^{\circ} \mathrm{C}$ for $10 \mathrm{~min}$. PCR products yielding bands of appropriate size were purified using the Montage PCR Cleanup Kit (Millipore). Cleaned PCR samples were quantified using a NanoDrop 1000 Spectrophotometer (Thermo Scientific). Each primer was diluted to $4.0 \mathrm{pmol} / \mu \mathrm{L}$ to send out for sequencing with the PCR products. PCR products were diluted to 6.0, 7.5, and $11.5 \mathrm{ng} / \mu \mathrm{L}$ for H3, 16S, and CO1 respectively. Samples were sequenced at Eton Bioscience, Inc. (San Diego, CA).

Sequences were deposited in GenBank (http://www.ncbi.nlm.nih.gov/genbank/) with the accession numbers KC992314 for CO1, KC992313 for 16S, and KC992315 for H3. Sequences of other species of Melibe and Tethys fimbria Linnaeus, 1767 were downloaded from GenBank (Table 1) and included in the phylogenetic analysis. Sequences for each gene were assembled and edited using GENEIOUS Pro 4.7.4 (Drummond et al. 2010). GENEIOUS Pro 4.7.4 was also used to extract the consensus sequence between the primer regions, construct the alignment for each gene using the default parameters, concatenate the alignments, translate the CO1 sequences intro protein sequences and align the protein sequences. The sequences were not trimmed 
Table I. Specimens sequenced, including locality information, collection voucher numbers and GenBank accession numbers.

\begin{tabular}{l|l|l|l|l|l}
\hline \multirow{2}{*}{ Species } & \multirow{2}{*}{ Voucher } & \multirow{2}{*}{ Locality } & \multicolumn{3}{|c}{ GenBank accession numbers } \\
\cline { 4 - 6 } & & & \multicolumn{1}{c}{ CO1 } & \multicolumn{1}{c}{$\mathbf{1 6 5}$} & \multicolumn{1}{c}{ H3 } \\
\hline T. fimbria & - & - & AY345035 & AY345035 & EF133468 \\
\hline$M$. leonina & LACM174849 & California, USA & GQ292059 & GU339202 & - \\
\hline$M$. digitata & CASIZ175724 & Philippines & JX306069 & JX306061 & JX306076 \\
\hline$M$. digitata & CASIZ177478 & Philippines & HM162699 & HM162617 & HM162523 \\
\hline$M$. viridis & CASIZ176981 & Mozambique & JX306075 & JX306068 & JX306083 \\
\hline$M$. viridis & CASIZ177524 & Philippines & HM162700 & HM162618 & HM162524 \\
\hline$M$. rosea & CASIZ175734 & South Africa & JX306070 & JX306063 & JX306078 \\
\hline$M$. rosea & CASIZ176355 & South Africa & JX306071 & JX306064 & JX306079 \\
\hline$M$. rosea & CASIZ176367 & South Africa & JX306073 & JX306066 & JX306081 \\
\hline$M$. rosea & CASIZ176356 & South Africa & JX306072 & JX306065 & JX306080 \\
\hline$M$. rosea & CASIZ176392 & South Africa & HM162701 & HM162620 & HM162526 \\
\hline$M$. engeli & CASIZ177625 & Philippines & - & HM162619 & HM162525 \\
\hline$M$. engeli & CASIZ177757 & Philippines & - & JX306062 & JX306077 \\
\hline$M$. arianeae & LACM3259 & Florida, USA & KC992314 & KC992313 & KC992315 \\
\hline
\end{tabular}

after alignment. A total of 328 bp for $\mathrm{H} 3,453 \mathrm{bp}$ for $16 \mathrm{~S}$, and $657 \mathrm{bp}$ for $\mathrm{CO} 1$ including gaps were used for the phylogenetic analyses.

\section{Phylogenetic analyses}

To assess whether $\mathrm{H} 3,16 \mathrm{~S}$, and $\mathrm{CO} 1$ have significantly conflicting signals the incongruence length difference (ILD) test (Mickevich and Farris 1981, Farris et al. 1994), implemented in PAUP*4.0 as the partition homogeneity test (Swofford 2002), was conducted for all genes combined. The levels of saturation for each gene and for the first and second versus third codon positions of $\mathrm{CO} 1$ and $\mathrm{H} 3$ were investigated using the substitution saturation test developed by Xia et al. (2003) and Xia and Lemey (2009) implemented in the program DAMBE 4.0 (Xia and Xie 2001).

The Akaike information criterion (Akaike 1974) was executed in MRMODELTEST 2.3 (Nylander 2004) to determine the best-fit model of evolution. Bayesian analyses were executed in MRBAYES 3.2.1 (Huelsenbeck and Ronquist 2001), partitioned by gene (unlinked), with Tethys fimbria as the outgroup. Outgroup selection was based on the sister relationship between Tethys and Melibe (Gosliner and Pola 2012). The Markov chain Monte Carlo analysis was run with two runs of six chains for ten million generations, with sampling every 100 generations. Effective sample sizes and convergence of runs were assessed using TRACER 1.4.1 (Rambaut and Drummond 2007). The default $25 \%$ burn-in was applied before constructing majority-rule consensus tree/s. 


\section{Results}

The saturation analysis showed insignificant levels of saturation for all three genes, CO1: Iss $(0.4398)<$ Iss.c $(0.7384), P=0.000 ; 16 S$ : Iss $(0.6502)<$ Iss.c $(0.7087), P=$ 0.007 ; H3: Iss $(0.5591)<$ Iss.c $(0.7193), P=0.000$. The ILD test showed NS conflicting signals between the genes combined: $\mathrm{CO} 1$ vs. $\mathrm{H} 3(P=0.99)$, and $16 \mathrm{~S}$ vs. $\mathrm{H} 3(P$ $=0.08)$, except CO1 vs. $16 \mathrm{~S}(P=0.001)$. MRMODELTEST 2.3 selected the models $\mathrm{GTR}+\mathrm{I}+\mathrm{G}$ for $\mathrm{CO} 1$ and $16 \mathrm{~S}$ and GTR+I for H3 (CO1 $\gamma$ shape $=0.34$, proportion of invariant sites $=0.26 ; 16 \mathrm{~S} \gamma$ shape $=0.84$, proportion of invariant sites $=0.24 ; \mathrm{H} 3$ proportion of invariant sites $=0.81$ ).

The combined analysis of the three genes $(\mathrm{H} 3,16 \mathrm{~S}$, and $\mathrm{CO} 1)$ produced a consensus Bayesian tree in which the monophyly of Melibe is well supported, posterior probability (pp) $=1$ (Fig. 1). Within Melibe, the temperate species M. leonina is the most basal, however this result must be taken cautiously as several other species were not included in the analysis. For the rest of the species analyzed, $M$. arianeae sp. n. is sister to the tropical Indo-Pacific and South African taxa ( $\mathrm{pp}=1)$, which includes the Mediterranean non-native $M$. viridis as well as $M$. engeli, the species morphologically more similar to $M$. arianeae. All the species with more than one specimen included in

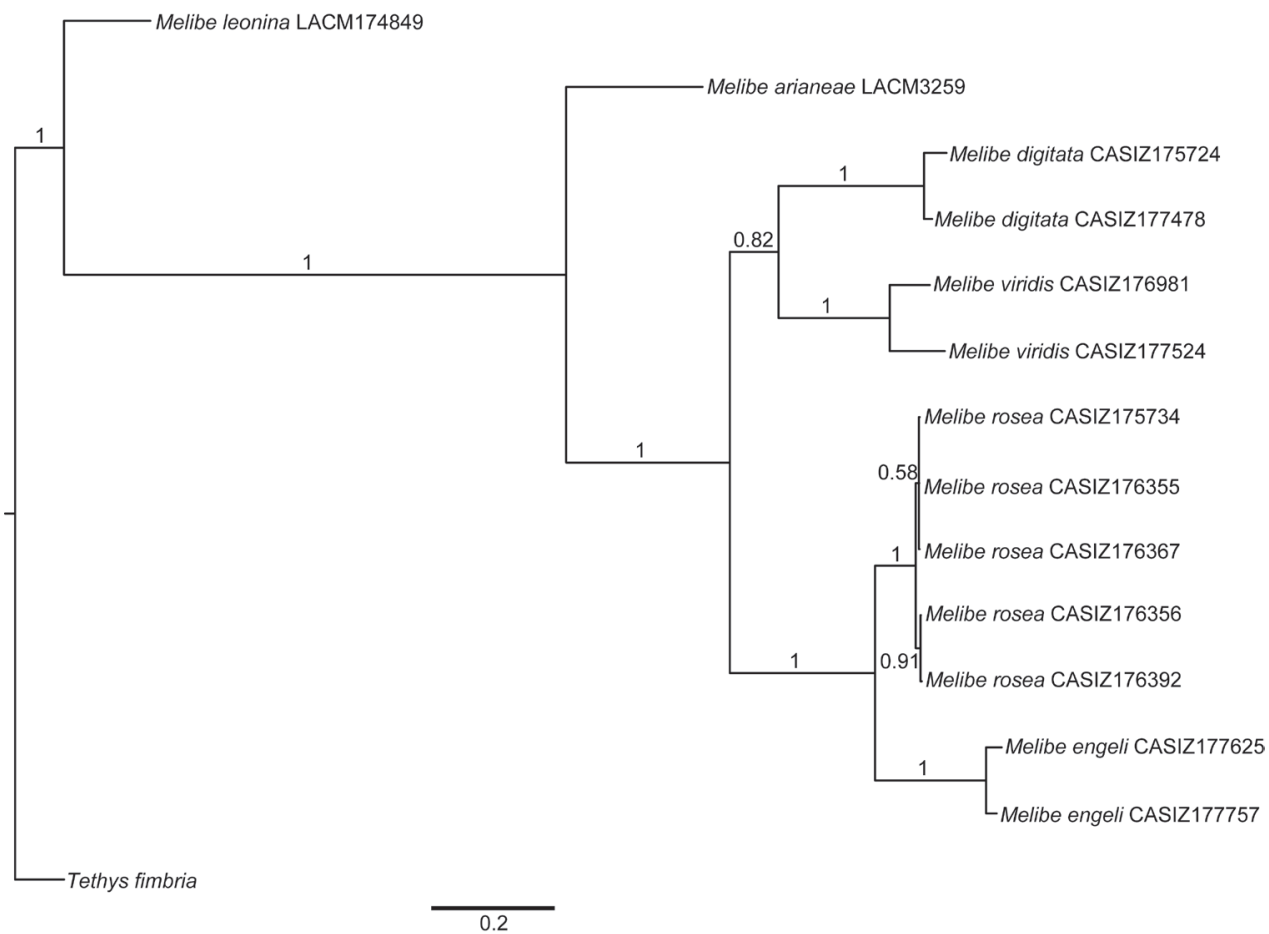

Figure I. Bayesian consensus tree of Melibe including museum voucher numbers and posterior probabilities. Abbreviations: CASIZ, California Academy of Sciences, Invertebrate Zoology; LACM, Natural History Museum of Los Angeles County. 
the analysis ( $M$. digitata, $M$. viridis, $M$. rosea and $M$. engeli) are monophyletic and well supported $(\mathrm{pp}=1)$.

When aligned with other species of opisthobranchs including Tethys, the CO1 sequence of $M$. arianeae as well as those of other tropical species of Melibe available in GenBank show 4 codon deletions. These codons are in positions 87-89, 352-354, $470-472$, and 473-475 (2) of the partial sequence alignment.

\section{Systematics}

Melibe arianeae sp. $\mathbf{n}$.

urn:Isid:zoobank.org:act:B9B242B1-9440-4AC3-88D9-A7260986172E

http://species-id.net/wiki/Melibe_arianeae

Figs 2-4

Melibe sp. Valdés et al., 2006: 234-235.

Type-locality. Lake Worth Lagoon, Palm Beach County, Florida (26.782781, -80.04468), $3 \mathrm{~m}$ depth, $6 \mathrm{~mm}$ preserved length, April 6, 2013, A. Dimitris leg.

Type-specimens. Holotype preserved in ethanol $95 \%$, dissected but no organs removed (LACM 3258). Paratype preserved in ethanol 95\%, dissected, reproductive system in the same vial, stomach on a SEM stub (LACM 3259).

Description. The living animals are nearly transparent, with numerous orange flecks and opaque white blotches all over its surface, and orange-brownish colored internal organs (Fig. 2). The body is limaciform and elongate, somewhat compressed anterolaterally, tapering posteriorly into a long, conical posterior end of the foot. The entire body surface, including cerata and rhinophoral sheaths are covered by numerous minute, opaque white tubercles. In the center of the dorsum of the holotype there are several (8) transparent tentacular papillae of different sizes, also covered with small white tubercles and having opaque white apices. The foot sole is wider anteriorly, it is covered with orange flecks and opaque white blotches as the dorsal surface, but it also has a faint white rim. The circular oral hood is small compared to the rest of the body. The margin of the hood is entire (with no indentations) and bears two rows of elongate papillae. There are papillae on the dorsal surface of the hood, generally resembling those on the body surface, and more concentrated towards the anterior margin. The rhinophores emerge from the posterior end of the oral hood. The rhinophores have 3-4 perfoliations. The rhinophoral sheaths are somewhat inflated and cylindrical, lacking a leaf-like posterior process. The sheaths have 2-3 posterior papillae. The cerata are inflated, oval, completely covered with small tubercles that give it a broadly warty look. Their distal ends of the cerata are either simple, bifurcate or trifurcate, independently of their size. The cerata are transparent, and the branches of the digestive gland within them are visible as a brownish axis. There are seven cerata alternating on each side of the dorsal midline of the holotype. The anus is located dorsol-lateraly, midway 


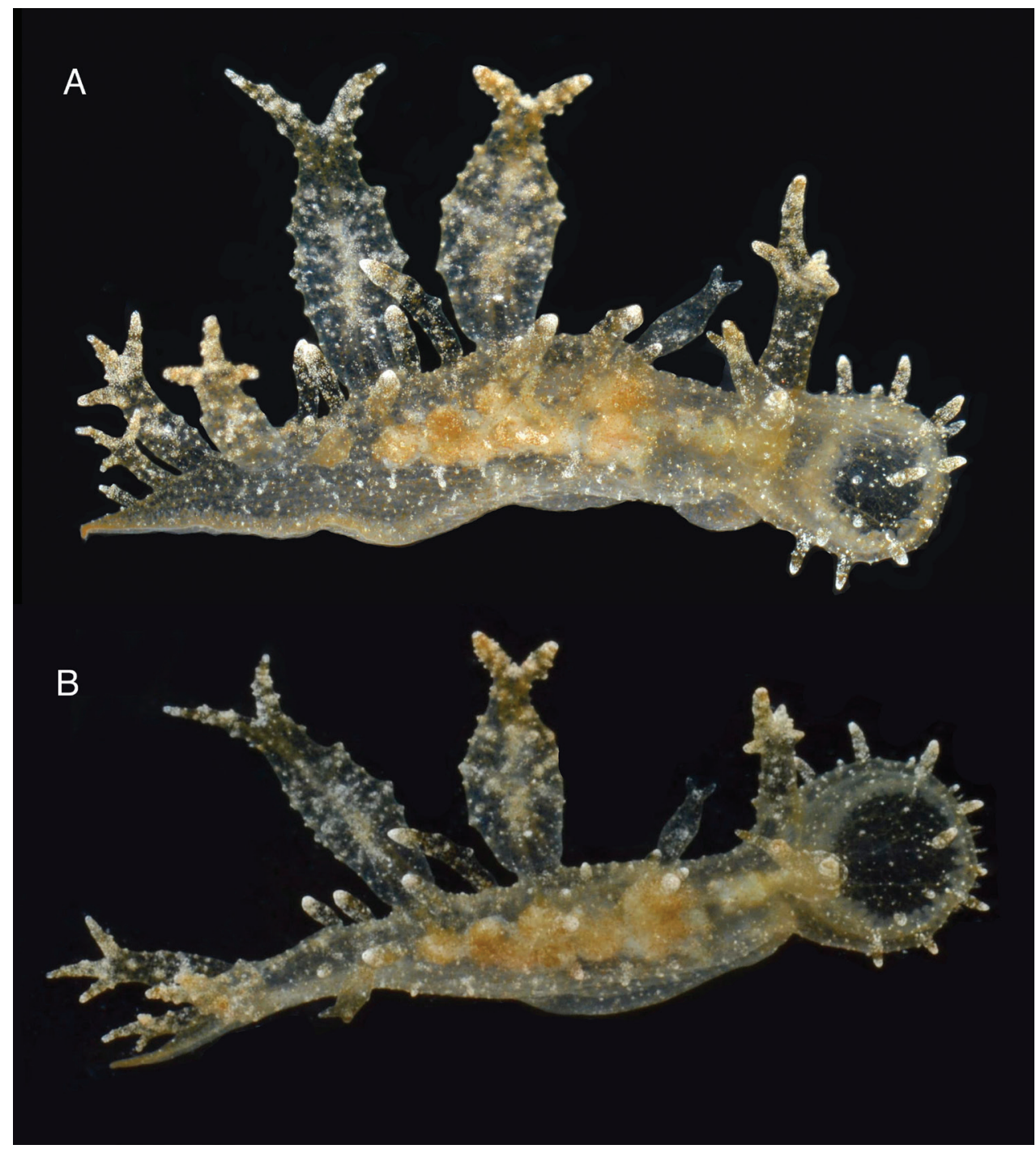

Figure 2. Two views of the holotype of Melibe arianeae sp. n. (LACM 3258). A. Dorsolateral view showing the right side of the animal. B. Dorsal view showing the oral hood border through the semitransparent skin.

between the first and second anterior cerata. The position of the nephroproct could not be determined. The gonopore is lateral, anterior to the anteriormost right ceras. There are no papillae associated with the gonopore.

The buccal mass is devoid of a radula but contains a pair of simple, chitinous jaws. The jaws (not illustrated) have smooth borders and lack denticles on the masticatory border. The short esophagus emerges from the posterior end of the buccal mass and expands into a muscular stomach (Fig. 3B). Two small salivary glands are located laterally, one on each side of the buccal mass. The posterior portion of the stomach contains 


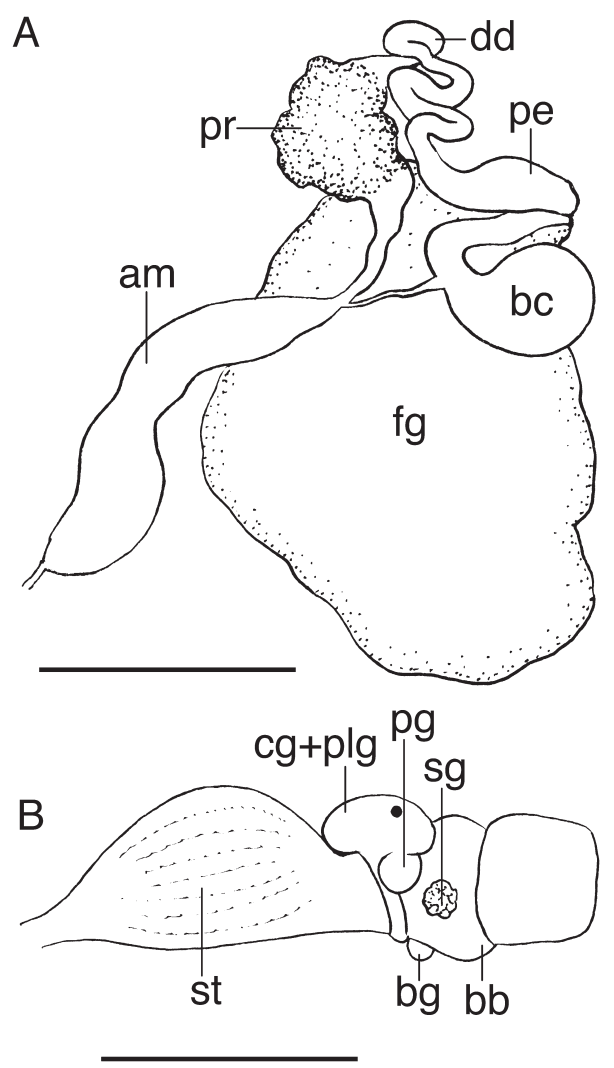

Figure 3. A Reproductive system of the paratype of $M$. arianeae sp. n. (LACM 3259) B Anterior portion of the digestive system of the holotype of $M$. arianeae sp. n. (LACM 3258). Scale bars $=1 \mathrm{~mm}$. Abbreviations: am, ampulla; bb, buccal bulb; bc, bursa copulatrix; bg, buccal ganglion; cg, cerebral ganglion; dd, deferent duct; fg, female gland complex; pe, penis; plg, pleural ganglion; pg, pedal ganglion; pr, prostate; sg, salivary gland; st, stomach.

18 elongate, thick and robust chitinous plates of various sizes (Fig. 4). The reproductive system is triaulic and contains a series of four spherical, well-separated ovotestis bodies, connected to a large ampulla. The ampulla connects into the female gland complex (Fig. 3A) near the point where the prostate emerges. The prostate is a short and wide glandular structure connected to a long, and convoluted deferent duct that expands distally into the penial sac. The vagina is short and wide and connects directly into a large bursa copulatrix. The narrow and straight uterine duct connects to the female gland complex. A serial seminal receptacle (present in other species of Melibe) was not observed. The central nervous system (Fig. 3B) is located above the esophagus and contains a fused pair of cerebral and pleural ganglia, as well as a pair of pedal ganglia. The buccal ganglia are located at the proximal end of the buccal mass.

Etymology. This species is named for Ariane Dimitris, amateur naturalist and passionate sea slug enthusiast, who collected the specimens here examined. 


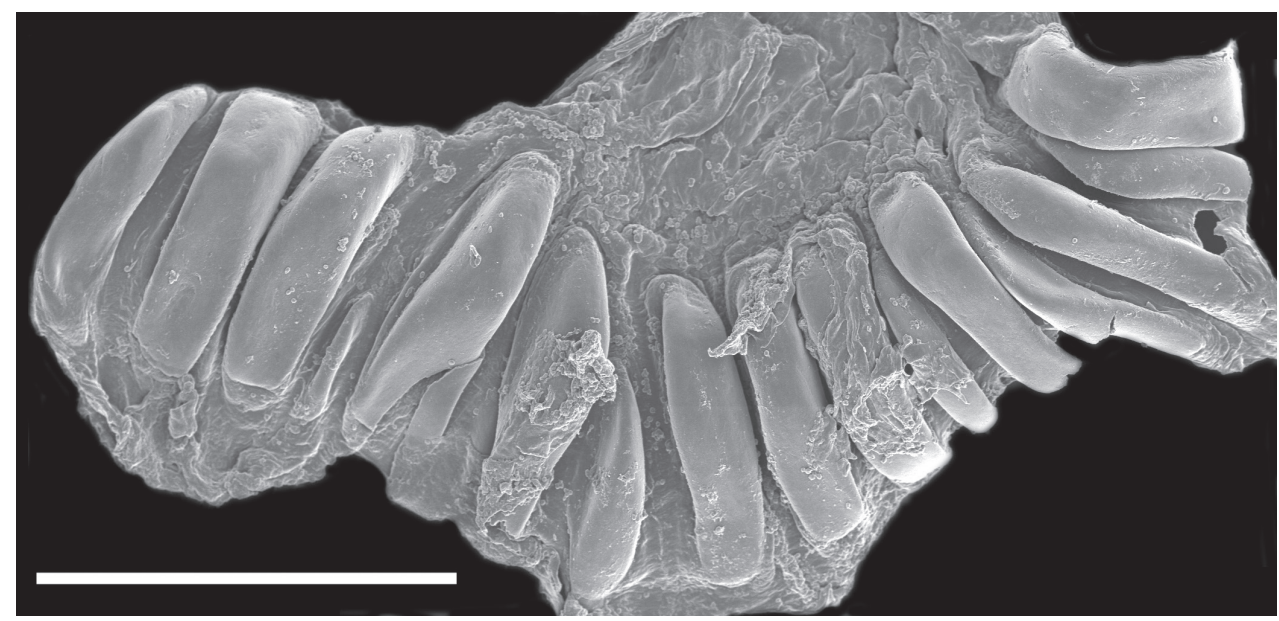

Figure 4. Scanning electron micrograph of the dissected stomach of the paratype of $M$. arianeae sp. $\mathrm{n}$. (LACM 3259) showing the stomach plates. Scale bar $=500 \mu \mathrm{m}$.

\section{Discussion}

Melibe arianeae is well differentiated morphologically relative to other congeners (discussed below). Molecular evidence is provided to support the placement of this new species in Melibe and to compare it to other species for which sequence data are available. There are large gaps in the molecular coverage of Melibe, thus comparison to all other species is not possible at this point. However, the phylogenetic tree here presented shows that $M$. arianeae is sister to a well-supported clade containing some of the most morphologically similar species to $M$. arianeae.

Melibe arianeae is externally most similar to $M$. engeli, originally described from New Caledonia and recently reported from Japan, the Hawaiian Islands and the Philippines (Gosliner and Smith 2003). Both species have a nearly transparent body with large cerata covered with conical tubercles and having bifurcated or trifurcated tips, as well as a large oral hood with two rows of papillae. Distinguishable characteristics include the absence of leaf-like posterior processes on the rhinophoral sheaths of $M$. arianeae and the lack of a vestibular gland in this species, both present in M. engeli (Gosliner and Smith 2003). The body papillae of $M$. engeli are more conical than those of $M$. arianeae and the cerata of $M$. engeli are covered with large papillae giving them a serrate appearance (Gosliner et al. 2008); these are absent in $M$. arianeae. Additionally, $M$. engeli is much larger, reaching up to $45 \mathrm{~mm}$ in length (Gosliner et al. 2008), whereas all specimens of $M$. arianeae are smaller than $15 \mathrm{~mm}$. Additionally, M. engeli and $M$. arianeae are genetically distinct, with a pairwise identity of $71.4 \%$ in $16 \mathrm{~S}$ and $96 \%$ in $\mathrm{H} 3$ (there are no $\mathrm{CO} 1$ sequences available for $M$. engeli). For comparison, within species pairwise identity values in Melibe range between $96.2-99.3 \%$ for $16 \mathrm{~S}$ and between $99.3-100 \%$ for $\mathrm{H} 3$.

All other species of Melibe examined and reviewed by Gosliner and Smith (2003) and Gosliner and Pola (2012) are externally easily distinguishable from M. arianeae. The California species M. leonina has flat, smooth, leaf-like cerata and a large oral 
hood with comparatively small rhinophores. The Australian species $M$. australis and $M$. maugeana are also easily distinguishable; $M$. australis has short, densely papillate flask-like cerata, and a round oral hood with a thick margin, whereas $M$. mangeana has a very large oral hood and few, long and cylindrical or fusiform cerata. The other two species found in the Atlantic, the South African M. rosea and M. liltvedi, are also clearly different; $M$. rosea has a pinkish general color, a large oral hood, and irregular and small club-shaped certata, and $M$. liltvedi has a comparatively small hood and very characteristic club-shaped, very large cerata. The tropical Indo-Pacific species exhibit a remarkable morphological diversity that makes most species easily identifiable. All the species are illustrated in Gosliner et al. (2008) based on live animals and here compared to $M$. arianeae. Melibe megaceras is a very distinctive species with very elongate and bifurcate cerata and a relatively small oral hood. Melibe digitata has long cerata with the apices densely covered with long papillae. Melibe minuta has long, highly ramified cerata ending in multifid acutely tapering apices. Melibe tuberculata is easily identifiable because of the presence of large, stalked tubercles on the cerata. Melibe papillosa and M. pilosa are very similar externally, both have a large oral hood and apically flattened cerata with a regular wedge shaped margin, bearing a few thin papillae. Melibe bucephala is a large species with an incised oral hood, the body covered with papillae and the cerata with large apical digitations. Melibe coralophilia resembles a live coral head, and it is densely covered with tubercles that form a mid-dorsal crest and cover the surface of the cerata. Melibe colemani is a transparent species with a series of white interconnecting digestive gland ducts visible throughout the body. Melibe viridis, which has been reported from the Mediterranean Sea, is distinguishable from $M$. arianeae by having a large oral hood and flattened, saccate, oval to cylindrical cerata with tubercular and papillate surfaces.

The specimen of Melibe sp. illustrated by Valdés et al. (2006) from Honduras probably is $M$. arianeae as it shares a similar external morphology, but this needs to be confirmed with examination of specimens. If this record is confirmed the known range of $M$. arianeae includes Florida and Honduras.

One of the most intriguing aspects of the genetics of Melibe is the presence of four deletions in the sequence of the cytochrome c oxidase subunit 1 protein in tropical congeners and $M$. rosea from South Africa. A protein alignment revealed that these deletions resulted in the loss of 4 residues in the cytochrome c oxidase subunit 1 protein. The structure of the cytochrome c oxidase of Paracoccus denitrificans was reconstructed by Iwata et al. (1995) who found that the subunit 1 contains 12 membrane-spanning, primarily helical segments and binds to haem $a$ and the haem $a_{3}$-copper B binuclear center where molecular oxygen is reduced. The alignment of the Melibe arianeae cytochrome c oxidase subunit 1 sequence with the annotated sequence of $P$. denitrificans based on the structural data collected by Iwata et al. (1995), shows that the residue deletions are located at the very beginning of helix II and in between helical segments III-IV and IV-V. These deletions do not seem to be affecting the shape of important structural elements, thus their functional implications might be limited. However, the fact that they are only present in tropical species of Melibe and the South African species $M$. rosea among all nudibranchs sequenced to date (including the temperate spe- 
cies Melibe leonina and the closely related Mediterranean species Tethys fimbria), and that some of them are located in highly conserved regions, suggest that they could have important fitness effects for the respiratory electron transport chain of mitochondria.

\section{Conclusion}

Molecular and morphological evidence confirmed that the specimens from Florida here examined belong to Melibe and therefore this paper is the first confirmed record of this group in the tropical western Atlantic Ocean. Morphological examinations also confirmed that these specimens constitute an undescribed species, which is morphologically distinct from other species of Melibe described to date. Additionally, these specimens are genetically distinct from other species of Melibe so far sequenced. Our knowledge of the phylogeny of Melibe is spotty, as many species have not been sequenced yet, thus few conclusions can be drawn from the Bayesian consensus tree. However, it clear that the tropical Indo-Pacific species studied so far form a monophyletic group. The presence of four deletions in the sequence of the cytochrome c oxidase subunit 1 protein in some Melibe could have important implications to understand protein function and selection on mitochondrial genes.

\section{Acknowledgments}

We are extremely grateful to Ariane Dimitris for providing specimens that were essential for the completion this project. Lindsey Groves from the LACM assisted with access to the collection and curation of specimens. This paper was supported by a Cal Poly Pomona Research, Scholarship, and Creative Activity grant and a FuTURE Kellogg Minigrant to A. Valdés as well as a scholarship to E. Espinoza from the NIH MBRS Research Initiative for Scientific Enhancement (RISE) grant to Cal Poly Pomona (2 R25 GM061190-05A2). The SEM work was conducted at the Natural History Museum of Los Angeles County, supported by the National Science Foundation under MRI grant DBI-0216506 to A. Valdés et al., with the assistance of Giar-Ann Kung. Two anonymous reviewers and the editor (Robert Hershler) made constructive comments that substantially improved the manuscript.

\section{References}

Akaike H (1974) A New Look at the Statistical Model Identifications. Institute of Electrical and Electronics Engineers Transactions on Automatic Control 19: 716-723.

Colgan DJ, McLauchlan A, Wilson GDF, Livingston SP, Edgecombe GD, Macaranas J, Cassis G, Gray MR (1998) Histone H3 and U2 snRNA DNA sequences and arthropod molecular evolution. Australian Journal of Zoology 46: 419-437. 
Drummond AJ, Ashton B, Cheung M, Heled J, Kearse M, Moir R, Stones-Havas S, Thierer T, Wilson AC (2010) Geneious v 4.8 [Online]. Biomatters. http://www.geneious.com/web/ geneious/geneious-versions [accessed 3 March 2010]

Farris JS, Källersjö M, Kluge AG, Bult C (1994) Testing significance of incongruence. Cladistics 10: 315-319.

Folmer O, Black M, Hoeh W, Lutz R, Vrijenhoek R (1994) DNA primers for amplification of mitochondrial cytochrome c oxidase subunit I from diverse metazoan invertebrates. Molecular Marine Biology and Biotechnology 3: 294-299.

Gosliner TM, Behrens DW, Valdés A (2008) Indo-Pacific nudibranchs and sea slugs. A field guide to the World's most diverse fauna. Sea Challengers, Gig Harbor, Washington, 426 pp.

Gosliner TM, Pola M (2012) Diversification of filter-feeding nudibranchs: two remarkable new species of Melibe (Opisthobranchia: Tethyiidae) from the tropical western Pacific. Systematics and Biodiversity 10: 333-349.

Gosliner TM, Smith VG (2003) Systematic review and phylogenetic analysis of the nudibranchs genus Melibe (Opisthobranchia: Dendronotacea) with descriptions of three new species. Proceedings of the California Academy of Sciences 54: 9-21.

Huelsenbeck JP, Ronquist F (2001) MrBayes: Bayesian inference of phylogeny. Bioinformatics 17: 754-755.

Iwata S, Ostermeier C, Ludwig B, Michel H (1995) Structure at 2.8 Å resolution of cytochrome c oxidase from Paracoccus denitrificans. Nature 376: 660-669.

Mickevich MF, Farris JS (1981) The implications of congruence in Menidia. Systematic Zoology 30: 351-370.

Nylander JAA (2004) MrModeltest ver. 2 [Online]. Evolutionary Biology Centre, Uppsala University, Uppsala. http://www.abc.se/-nylander [accessed 28 October 2010]

Palumbi SR (1996) Nucleic acids II: The polymerase chain reaction. In: Hillis DM, Moritz C, Mable BK (Eds) Molecular Systematics. Sinauer, Sunderland, Massachusetts, 205-247.

Rambaut A, Drummond A.J (2007) Tracer v1.4 [Online]. http://tree.bio.ed.ac.uk/software/ tracer/ [accessed 28 October 2010]

Swofford DL (2002) PAUP*: Phylogenetic analysis using parsimony (*and other methods). Ver. 4. Sinauer, Sunderland, Massachusetts.

Thompson TE, Crampton DM (1984) Biology of Melibe fimbriata, a conspicuous opisthobranch mollusc of the Indian Ocean, which has now invaded the Mediterranean Sea. Journal of Molluscan Studies 50: 113-121.

Valdés A, Hamann J, Behrens DW, DuPont A (2006) Caribbean sea slugs. A field guide to the opisthobranch mollusks from the tropical northwestern Atlantic. Sea Challengers, Gig Harbor, Washington, 289 pp.

Xia X, Lemey P (2009) Assessing substitution saturation with DAMBE. In: Lemey P, Salemi M, Vandamme A-M (Eds) The Phylogenetic Handbook: A Practical Approach to DNA and Protein Phylogeny, $2^{\text {nd }}$ Edition. Cambridge University Press, Cambridge, UK, 615-630.

Xia X, Xie Z (2001) DAMBE: Data analysis in molecular biology and evolution. Journal of Heredity 92: 371-373.

Xia X, Xie Z, Salemi M, Chen L, Wang Y (2003) An index of substitution saturation and its application. Molecular Phylogenetics and Evolution 26: 1-7. 